\title{
Mineral nutrients of beech (Fagus sylvatica) bark in relation to frost sensitivity and soil treatments in southern Sweden
}

\author{
Anna Maria Jönsson* \\ Dept. of Ecology, Forest Ecology, Lund University, Ecology Building, 22362 Lund, Sweden
}

(Received 25 May 1999; accepted 16 August 1999)

\begin{abstract}
Concentration of nutrients and balance between nutrients in trees can affect tree vitality, and are dependent on soil conditions and atmospheric deposition. The aim of this investigation was to survey the concentration of nutrients in beech bark and to look for relationships with the frost sensitivity of the bark. Beech trees with bark lesions were compared to undamaged beech trees on five experimental sites with control plots, plots treated with nitrogen, ash or lime. Trees treated with lime had increased Ca/Al ratio and decreased concentrations of $\mathrm{Mn}$ and $\mathrm{B}$. Negative influence from $\mathrm{N}$ fertilization could be traced in the concentration of nutrients in the bark seven years after treatment, but the absence of new lesions indicated that the vigour of the trees has increased. The frost sensitivity was correlated to the nutrient content. Trees with lesions had higher concentrations of $\mathrm{N}$ and $\mathrm{Al}$, indicating influence of soil acidity.
\end{abstract}

index of injury / lime / nitrogen / wood ash

Résumé - Influence de la composition en éléments minéraux de l'écorce en relation avec les traitements chimiques apportés au sol sur la sensibilité au froid du hêtre dans le sud de la Suède. La concentration et l'équilibre des éléments minéraux dans les arbres peut affecter leur vitalité et sont dépendants des conditions de sol et des dépôts atmosphériques. Le but de ce travail a été d'étudier la concentration des éléments minéraux dans l'écorce du hêtre et d'essayer de mettre en évidence des relations avec la sensibilité au froid des écorces. Les arbres avec des lésions au niveau de l'écorce étaient comparés avec des arbres indemnes dans cinq sites expérimentaux comprenant des placettes témoins et des placettes traitées avec apport d'azote, de cendres ou de chaux. Les arbres traités avec apport de chaux ont vu un accroissement du rapport $\mathrm{Ca} / \mathrm{Al}$ et une décroissance de la concentration en manganèse et en bore. Une influence négative de la fertilisation azotée peut être retrouvée sur la concentration en éléments minéraux de l'écorce sept ans après le traitement. Mais l'absence de nouvelles lésions indique que la vigueur des arbres a été accrue. La sensibilité au froid a été correlée avec la teneur en éléments minéraux. Les arbres avec des lésions ont présenté une plus grande concentration en azote et en Al reflétant l'influence de l'acidité du sol.

sensibilité au froid / chaux / azote / cendres

\section{INTRODUCTION}

Nutrients and their relative proportions to each other in trees are important for tree vitality. They are influenced by air pollution, nitrogen deposition and soil acidification. A high deposition of $\mathrm{S}$ and $\mathrm{N}$ in southern
Swedish beech forests has led to increased forest soil acidification [30]. The amount of exchangeable Al has doubled, and the amount of base cations $(\mathrm{Ca}, \mathrm{Mg}, \mathrm{K}$, $\mathrm{Zn}$ ) has decreased on average by $50 \%$ during the last 40 years [10]. From an analysis of nutrients in leaves from beeches grown in Scania it was concluded that many of

* Correspondence and reprints

Tel. 4646222 4247; Fax. 4646222 4423; e-mail: Anna-Maria.Jonsson@ planteco.lu.se 
the trees had suboptimal concentrations of $\mathrm{K}, \mathrm{Mg}$ and $\mathrm{P}$ whereas the $\mathrm{N}$ concentration in general was high [3].

The more acid soil, the lower the cation-holding capacity of the soil particles. In the organic layer the charges of the cation exchange complexes are $\mathrm{pH}$ dependent, and in the mineral soil the cation exchange complexes become increasingly saturated with $\mathrm{Al}$ at lower $\mathrm{pH}$ [30]. The solubility of $\mathrm{Mn}$ and Fe increases at low $\mathrm{pH}$ and in anaerobic conditions [23]. This increases the concentration of cations in the water solution, and the part that is not taken up by the organisms is lost from the ecosystem by leakage. At the same time, the trees grow better with an increased $\mathrm{N}$ supply, which increases the uptake of cations and enhances biological soil acidification [21]. Deficiencies of base cations may arise if weathering is insufficient to meet nutrient demands [5, $11,26,31]$.

Due to nutrient imbalances, trees subjected to an increased $\mathrm{N}$ supply may become more sensitive to environmental stress, for instance frost and drought [21, 24]. Environmental stress changes physiological and chemical conditions within the trees which predisposes the trees to lethal attacks by opportunistic pathogenic organisms [33]. A high $\mathrm{N}$ level can increase the frequency of frost injuries in trees through lowered starch concentration and delayed hardening [8]. Bark lesions caused by frost injuries are frequently observed on declining oaks, which together with insect defoliation and drought are thought to be primary stress factors contributing to oak decline. Lesions that are not healed are invaded by pathogenic insects or fungi [16]. The frost injuries usually occur late in winter when the trees are not hardened [27].

Lesions on beeches can also be attributed to the beech bark disease. The disease is initiated by the insect Cryptococcus fagisuga that is more frequent on beech stems with high concentrations of amino acids [32]. Trees with $\mathrm{N}$ or $\mathrm{P}$ in excess or deficiency had increased sensitivity to the disease and low concentrations of $\mathrm{Ca}$ and $\mathrm{Mg}$ in the bark increased the severity of the necrosis [22].

A lowered $\mathrm{N}$ input to forest stands saturated with $\mathrm{N}$ quickly improved the chemical composition of the soil solution and after some years the trees responded with increased vigour $[6,7]$. Lime has been tested as a counter measure to soil acidification for many years. Soil conditions have been improved, acidity and the amount of free $\mathrm{Al}$ ions have been reduced. Wood ash and nonnitrogenous fertilizers are applied to improve the nutrient status [9]. Trees have nutrient reserves in the trunk which are used during the vegetative period, thus soil treatment is not expected to change their nutrient status within a short period [14]. The inner bark is composed of phloem tissue from preceding years, thus the response to fertilization is lower, but more persistent in bark tissue than in foliage [29].

The aim of this study was to survey the concentration of nutrients in beech bark and to evaluate effects of soil amendments and changes in $\mathrm{N}$ input. The aim was also to correlate the concentration of nutrients to the appearance of bark lesions and frost sensitivity of bark, measured as an index of injury.

\subsection{Hypotheses}

1. The nutrient concentration in bark differs from treatment to treatment. Trees treated with wood ash or lime were expected to have more base cations and less $\mathrm{Al}, \mathrm{Mn}$ and $\mathrm{Fe}$, whereas the situation for the $\mathrm{N}$-fertilized trees would be reversed;

2. Trees with bark lesions have lower concentrations of base cations and higher concentrations of N, Al, $\mathrm{Mn}$ and $\mathrm{Fe}$ compared to trees with undamaged bark;

3. Frost sensitivity, measured as an index of injury, can be related to the nutrient concentration in bark.

\section{MATERIAL AND METHODS}

Five beech forest sites in southernmost Sweden with trees approximately 100 years old were investigated in 1997. All experimental sites were designed as randomised blocks with three replicates, except Ynde that had only two replicates. Each site had control plots and plots treated with either lime, ash or nitrogen. The sites had different soil types with a big variation in order to increase the range of nutrient concentrations, which would make relationships between nutrient status and frost hardiness easier to detect.

- Svenstorp, a haplic podzol treated with $5000 \mathrm{~kg}$ lime $\mathrm{ha}^{-1}$ in December 1991. The lime contained $45 \% \mathrm{CaO}$ and $5 \% \mathrm{Mg}$;

- Floen, a cambic podzol also treated with $5000 \mathrm{~kg}$ lime ha $\mathrm{h}^{-1}$ in December 1991. The lime contained $46 \%$ $\mathrm{CaO}$ and $3 \% \mathrm{Mg}$;

- Maglehem, a dystric cambisol transitional to cambic arenosol, fertilised with nitrogen in 1985-1989, 66 and $198 \mathrm{~kg} \mathrm{NH}_{4} \mathrm{NO}_{3} \mathrm{ha}^{-1} \mathrm{yr}^{-1}$ for 5.5 years, in total $150 \mathrm{~kg} \mathrm{~N} \mathrm{ha}^{-1}$ and $450 \mathrm{~kg} \mathrm{~N}^{-1}$ respectively. The fertilizer also contained $4 \% \mathrm{CaCO}_{3}, 2 \% \mathrm{MgCO}_{3}$ and traces of other elements [5];

- Konga, a dystric cambisol, fertilized with $150 \mathrm{~kg}$ $\left(\mathrm{NH}_{4}\right)_{2} \mathrm{SO}_{4} \mathrm{ha}^{-1} \mathrm{yr}^{-1}$, started in 1989 and treated for three years, in total $450 \mathrm{~kg} \mathrm{~N} \mathrm{ha}^{-1}$. In $199183 \mathrm{~kg}$ $\mathrm{NH}_{4} \mathrm{H}_{2} \mathrm{PO}_{4}$-fertilization was added per ha on all plots; 
- Ynde, a cambic podzol in combination with haplic podzol, was treated in January 1990 with $5000 \mathrm{~kg}$ bark ash $\mathrm{ha}^{-1}$. The ash contained $19 \% \mathrm{Ca}, 28 \% \mathrm{Mg}$, $12 \% \mathrm{~K}$ and $4.8 \% \mathrm{P}$ [13].

The analysis of frost sensitivity was modified after Thomas and Blank (1996). It was measured in August since frost injuries often occurs when the trees are not hardened, and repeated in November when the trees were hardened. Trees were classed as undamaged or having bark lesions. Three trees with bark lesions and three undamaged trees were randomly chosen for both control and treatment on each site, however, at Maglehem no control tree with lesions was found. Algae and lichens were removed from the bark surface on the north side of the stem with a scraper. Bark samples, mainly phloem and cambial tissue, were taken approximately $1.3 \mathrm{~m}$ above ground with a hole puncher, $1 \mathrm{~cm}$ in diameter. The samples were kept in plastic test tubes with caps in order to prevent desiccation and transported in a cool-box to the laboratory. Bark thickness was measured and the samples were stored at $+5^{\circ} \mathrm{C}$ until the next morning when the freezing treatment began.

For each tree three pieces of bark (replicates) were stored at $+5{ }^{\circ} \mathrm{C}$ as control and three (+two for the nutrient analysis) were autoclaved for 20 minutes at $120{ }^{\circ} \mathrm{C}$. Three pieces of bark were exposed to the test temperature, $-10{ }^{\circ} \mathrm{C}$ or $-20{ }^{\circ} \mathrm{C}$, for 30 minutes. They were then thawed at $+5{ }^{\circ} \mathrm{C}$ for 10 hours.

Five $\mathrm{mL} 3 \%$ propanol was added to all bark samples, and they were incubated in darkness for 24 hours at $25{ }^{\circ} \mathrm{C}$. During that time ions from the bark tissue leaked into the propanol solution, the larger injury the higher leakage. The conductivity was measured with a CDM92 conductivity meter (radiometer, Copenhagen), reference temperature $20^{\circ} \mathrm{C}$. An index of injury ranging from $0=$ no freezing damage to $100=$ completely killed by freezing treatment was calculated:

$I_{\mathrm{t}} x m=100^{*}\left(R C_{\text {frozen }}-R C_{\text {control }}\right) /\left(1-R C_{\text {control }}\right)$,

$x=$ test temperature, $-10{ }^{\circ} \mathrm{C}$ or $-20{ }^{\circ} \mathrm{C}$,

$m=$ month, August (A) or November $(\mathrm{N})$,

$R C=R 1 / R 2$,

$R 1$ = conductivity for frozen or control samples/bark thickness,

$R 2=$ conductivity for autoclaved samples/bark thickness.

$N$ concentration was analysed using the Kjeldahlmethod. ICP-analysis was carried out for $\mathrm{Al}, \mathrm{B}, \mathrm{Ca}, \mathrm{Cu}$, $\mathrm{Fe}, \mathrm{K}, \mathrm{Mg}, \mathrm{Mn}, \mathrm{Na}, \mathrm{P}, \mathrm{S}$ and $\mathrm{Zn}$ on two autoclaved bark pieces taken in August. The propanol extract was analysed separately, to get a rough estimate of the concentration of elements in the cells and in the cell wall, so that the ions contributing to the conductivity and the frost tolerance in the cells could be estimated. The remaining bark was digested in concentrated and hot $\mathrm{HNO}_{3}$ before analysis. The concentrations were expressed as $\mathrm{mg} / \mathrm{g}$, and for multiple regression analysis as $\mathrm{mmol} / \mathrm{g}$.

In the text the following definitions were used:

(e) = elements in propanol extract of autoclaved bark,

(b) = elements remaining in bark after propanol extraction, digested in concentrated and hot $\mathrm{HNO}_{3}$,

(s) = the sum of propanol extract and the amount in remaining in bark after propanol extraction.

The value from the statistical test was given for (s) when the outcome of the statistical test for elements in extract (e) and elements bark (b) was equal, and not different from the test of their sum (s).

Statistical tests used: two-way anova, fixed model, Tukeys posthoc test, t-test, correlations and multiple regression, backward selection, were calculated in accordance with Sokal and Rohlf (1995). Significances were indicated with $*$ for the $5 \%$ level, ** for the $1 \%$ level and $* * *$ for the $0.1 \%$ level. The indices of injury from Svenstorp were omitted from the calculations of multiple regressions since reliable indices could not be calculated for four trees with the largest lesions. The conductivities measured from their bark pieces, subjected to the different treatments of an index of injury test, deviated strongly from the general pattern.

\section{RESULTS}

The mean concentration of nutrients in beech bark for all sites and treatments are presented in table I. The coefficients of variation were higher for micronutrients and $\mathrm{Al}$ than for macronutrients. More than $50 \%$ of $\mathrm{Al}, \mathrm{B}$ and $\mathrm{K}$ were extracted, but only little of $\mathrm{Cu}, \mathrm{Ca}$ and $\mathrm{S}$ (table II).

There were a few significant differences in concentration of nutrients among the control trees at Svenstorp, Maglehem, Ynde and Floen. The N content was higher at Svenstorp than at Ynde $\left(F=10.13^{* *}\right)$. Compared to control trees at the other sites, P-fertilized trees at Konga had lower concentrations of Al $\left(s t=-2.671^{*}\right)$, $\mathrm{Ca}\left(s t=-3.484^{* *}\right), \mathrm{S}(b t=-2.997 * *)$ and higher concentrations of $\mathrm{Cu}(e t=11.23 * * *), \mathrm{Fe}(s t=2.279 *)$, $\operatorname{Mg}(b t=2.353 *)(d f=26)$.

The Mn concentration varied considerably among the blocks at Ynde and Svenstorp. The four highest Mn concentrations were found in trees at Ynde standing in the block near a wet spot in the forest, the two highest in the control plot and the 3rd, 4th and 12th ranked in the treated plot beside it. In the other block the Mn 
Table I. The sum of mineral nutrients in extract and extracted bark of Fagus sylvatica taken in August from five different sites and treatments in southern Sweden. Concentrations significantly affected by soil treatment are marked with an *. Mean concentration (mg/g), standard deviation (sd) and coefficient of variation (cv) are presented.

\begin{tabular}{|c|c|c|c|c|c|c|c|c|c|c|c|c|c|}
\hline & \multicolumn{3}{|c|}{$\begin{array}{c}\text { all sites } \\
n=60\end{array}$} & \multicolumn{2}{|c|}{$\begin{array}{c}\text { Svenstorp } \\
n=12\end{array}$} & \multicolumn{2}{|c|}{$\begin{array}{l}\text { Floen } \\
n=12\end{array}$} & \multicolumn{2}{|c|}{$\begin{array}{c}\text { Maglehem } \\
n=12\end{array}$} & \multicolumn{2}{|c|}{$\begin{array}{l}\text { Konga } \\
n=12\end{array}$} & \multicolumn{2}{|c|}{$\begin{array}{c}\text { Ynde } \\
n=12\end{array}$} \\
\hline & $\mathrm{mg} / \mathrm{g}$ & & $\mathrm{cv}$ & $\mathrm{mg} / \mathrm{g}$ & $\mathrm{sd}$ & $\mathrm{mg} / \mathrm{g}$ & $\mathrm{sd}$ & $\mathrm{mg} / \mathrm{g}$ & sd & $\mathrm{mg} / \mathrm{g}$ & sd & $\mathrm{mg} / \mathrm{g}$ & sd \\
\hline $\mathrm{Al}$ & 0.008 & 005 & 0.650 & 0.012 & $O C$ & 006 & 0.00 & .004 & 0.00 & 0.004 & .00 & .011 & 0.004 \\
\hline$B$ & 0.022 & 0.024 & 1.060 & $* 0.018$ & 0.015 & .024 & 029 & 0.014 & 0.024 & 0.033 & & 0.022 & 0.007 \\
\hline $\mathrm{Ca}$ & 21.368 & 7.879 & 0.370 & 19.922 & 6.430 & 21.346 & 6.387 & 29.808 & 7.060 & 12.412 & 90 & 3.353 & 5.021 \\
\hline $\mathrm{Cu}$ & 0.003 & 0.002 & 0.560 & 0.004 & 0.002 & 0.003 & 0.002 & 0.003 & 0.002 & 0.003 & .001 & 0.002 & 0.001 \\
\hline $\mathrm{Fe}$ & .008 & 0.008 & 1.070 & 0.012 & 0.008 & 0.007 & 0.006 & 0.005 & 0.009 & $* 0.012$ & 0.010 & 0.003 & 0.003 \\
\hline K & 3.010 & 0.756 & 0.250 & 2.759 & 0.790 & 3.057 & 0.832 & 3.073 & 0.480 & $* 2.697$ & 0.630 & 3.467 & 0.846 \\
\hline $\mathrm{Mg}$ & .755 & 0.225 & 0.300 & 0.728 & 0.230 & 0.664 & 0.194 & 0.657 & 0.132 & 0.917 & 0.247 & 0.808 & 0.222 \\
\hline $\mathrm{Mn}$ & 8 & 0.493 & & 1.094 & 0.3 & $* 0.803$ & & 19 & 8 & 12 & & 60 & 0.638 \\
\hline $\mathbf{N}$ & 6.096 & 1.040 & 0.170 & 7.013 & 1.512 & 6.105 & 0.595 & 5.511 & 0.590 & 6.398 & 2 & 5.453 & 0.628 \\
\hline $\mathrm{Na}$ & 0.014 & 0.017 & 1.180 & 0.026 & 0.018 & 0.008 & 0.008 & 0.013 & 0.013 & 0.014 & 0.026 & 0.009 & 0.008 \\
\hline $\mathrm{P}$ & 0.390 & 0.086 & 0.220 & 0.360 & 0.073 & 0.387 & 0.065 & 0.389 & 0.067 & 0.357 & 0.061 & 0.455 & 0.122 \\
\hline S & 0.835 & 0.174 & 0.210 & 0.782 & 0.120 & 0.767 & 0.138 & 0.962 & 0.137 & 0.655 & 0.068 & 1.010 & 0.102 \\
\hline $\mathrm{Zn}$ & 0.020 & 0.024 & 1.200 & 0.018 & 0.012 & 0.016 & 0.012 & 0.010 & 0.009 & 0.013 & 0.007 & 0.043 & 0.044 \\
\hline
\end{tabular}

Table II. Average percentage of elements in bark able to be extracted with $3 \%$ propanol solution after autoclaving $(n=60)$.

\begin{tabular}{lccc}
\hline & $\%$ & & $\%$ \\
\hline $\mathrm{Al}$ & 67 & $\mathrm{Mg}$ & 18 \\
$\mathrm{~B}$ & 61 & $\mathrm{Mn}$ & 11 \\
$\mathrm{Ca}$ & 2 & $\mathrm{Na}$ & 18 \\
$\mathrm{Cu}$ & 8 & $\mathrm{P}$ & 33 \\
$\mathrm{Fe}$ & 31 & $\mathrm{~S}$ & 7 \\
$\mathrm{~K}$ & 63 & $\mathrm{Zn}$ & 48 \\
\hline
\end{tabular}

concentrations were much lower, ranking order 19, 22, 44 respectively $17,33,34,37$ of all investigated trees. At Svenstorp the concentrations of $\mathrm{Fe}(\mathrm{s})$ and $\mathrm{Mn}(\mathrm{s})$ tended to be higher in trees standing at the bottom of the slope near a wet outflow area, than in trees standing in the middle of the slope. An exception to the general pattern was one undamaged control tree at the top of the slope with very high $\mathrm{Mn}$ and Fe concentrations (figure 1).

At Svenstorp the amount of B was significantly lower in trees treated with lime than in untreated trees. Trees treated with lime at Floen had lower concentration of $\mathrm{Mn}$, and the $\mathrm{Ca} / \mathrm{Al}$ ratio was higher. Trees treated with bark ash did not differ from control trees at Ynde. No significantly different nutrient concentrations were found among treatments at Maglehem. Trees fertilized with nitrogen at Konga had lower concentrations of extractable $\mathrm{Fe}$ and $\mathrm{K}$, and the $\mathrm{K} / \mathrm{N}$ ratio was lower (table III).

The control trees with lesions had elevated concentrations of $\mathrm{N}$ (figure 2), $\mathrm{Al}(\mathrm{b}), \mathrm{K}(\mathrm{b})$ and $\mathrm{P}(\mathrm{b})$. The same ten-
Table III. Elements significantly affected by the soil treatment. The \%-value indicates the difference between the mean concentration in treated trees compared to the mean concentration in control trees.

\begin{tabular}{lccc}
\hline site & element & $F$-value & $\%$ \\
\hline Svenstorp & $\mathrm{B}(\mathrm{s})$ & $5.299^{*}$ & -62 \\
Floen & $\mathrm{Mn}(\mathrm{s})$ & $29.4^{* * *}$ & -53 \\
Floen & $\mathrm{Ca} / \mathrm{Al}$ & $5.791^{*}$ & +47 \\
& & & \\
Konga & $\mathrm{Fe}(\mathrm{e})$ & $13.656^{* *}$ & -35 \\
Konga & $\mathrm{K}(\mathrm{e})$ & $9.526^{*}$ & -24 \\
Konga & $\mathrm{K} / \mathrm{N}$ & $5.999^{*}$ & -21 \\
\hline
\end{tabular}

dencies were found when including all trees in the calculations, but not as strong. At Svenstorp the damaged stems had higher concentrations of $K(s)$ and $\mathrm{Mg}(\mathrm{s})$, and the $\mathrm{K} / \mathrm{N}$ ratio was elevated compared to the undamaged trees. The Mn concentration was significantly lower in trees with lesions (b). At Ynde the trees with bark lesions had higher concentrations of $\mathrm{Al}(\mathrm{b}), \mathrm{Ca}(\mathrm{b})$, $\mathrm{P}(\mathrm{e})$ and $\mathrm{S}(\mathrm{b})$. At Maglehem trees with lesions had lower concentrations of $\mathrm{Ca}(\mathrm{e}), \mathrm{Fe}(\mathrm{b}), \mathrm{K}(\mathrm{s}), \mathrm{Mg}(\mathrm{e}), \mathrm{Mn}(\mathrm{e})$ and $\mathrm{P}(\mathrm{b})$ (table IV).

The indices of injury (table $V$ ) were dependent on 6 to 11 elements and the explanatory level was about $50 \%$, even in August when the trees were not hardened (table VI). The $\mathrm{N}$ concentration did not influence the index at all. The standard partial regression coefficients revealed that $\mathrm{Ca}(\mathrm{b})$ and $\mathrm{S}(\mathrm{b})$ were the two most 
$\mathrm{Mn} \mathrm{mg} / \mathrm{g}$

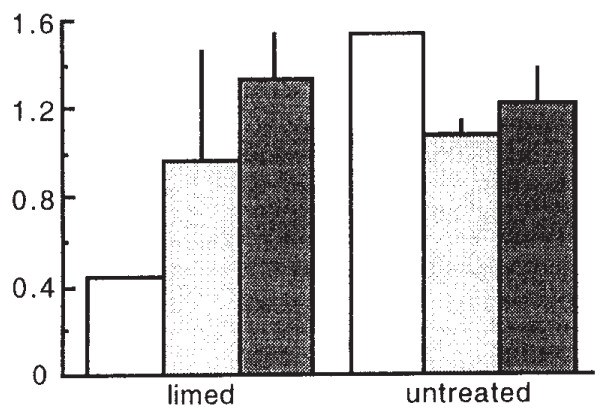

$\mathrm{Fe} \mathrm{mg} / \mathrm{g}$

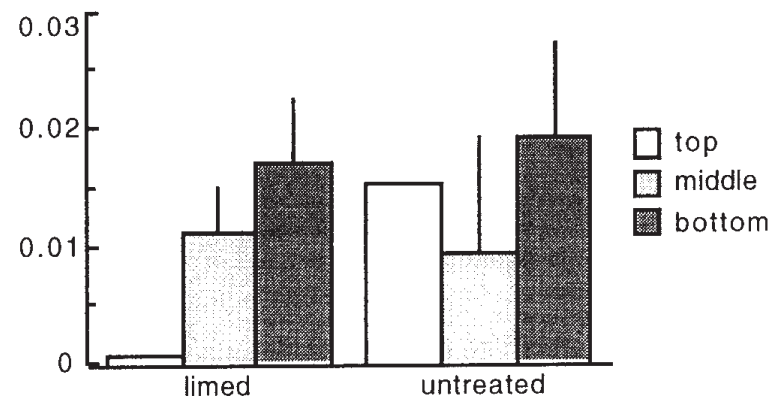

Figure 1. At Svenstorp the experimental plots were situated on rather a steep slope, about $20 \mathrm{~m}$ in length. The position on the terrain influenced the concentration of $\mathrm{Mn}$ and Fe in the trees. Standard deviations are indicated on the bars, $n=12$.

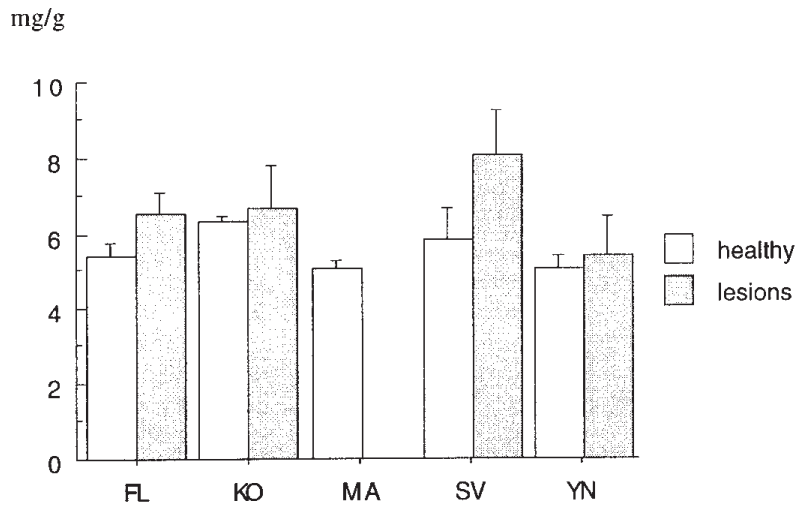

Figure 2. $\mathrm{N}$ concentrations $(\mathrm{mg} / \mathrm{g})$ for control trees at Floen (FL), Maglehem (MA), Svenstorp (SV) and Ynde (YN), and for P fertilized trees at Konga (KO). Trees with bark lesions had elevated $\mathrm{N}$ concentration compared to trees with undamaged stems. There was no control tree with bark lesion at Maglehem. Standard deviation is indicated by a line on top of each bar.

important elements in all equations, except $I_{\mathrm{t}} 20 \mathrm{~A}$. Trees with relatively high $\mathrm{Ca}$ and low $\mathrm{S}$ concentrations were less damaged and had hardened better. The conductivity of autoclaved samples (AC) was up to $82 \%$ explained by the following model, derived from multiple regression: $\mathrm{AC}=c+c_{1} \mathrm{~K}(\mathrm{e})+c_{2} \mathrm{Mg}(\mathrm{e})+c_{3} \mathrm{~S}(\mathrm{e})+c_{4} \mathrm{Al}(\mathrm{e})(F=$ $48.2 * * *)(c=$ constant $)$.
Table IV. The concentration of elements differed somewhat between trees with bark lesions and trees with undamaged stems. The \%-value indicates the difference between the mean concentration in trees with lesions compared to the mean concentration in trees with undamaged stems.

\begin{tabular}{lccc}
\hline site & element & $F$-value & $\%$ \\
\hline all controll & $\mathrm{N}$ & $5.06^{*}$ & +7 \\
$"$ & $\mathrm{Al}(\mathrm{b})$ & $10.26^{* *}$ & +200 \\
$"$ & $\mathrm{~K}(\mathrm{~b})$ & $8.22^{*}$ & +26 \\
& $\mathrm{P}(\mathrm{b})$ & $8.60^{*}$ & +16 \\
Svenstorp & $\mathrm{K}(\mathrm{s})$ & $10.369^{* *}$ & +49 \\
$"$ & $\mathrm{Mg}(\mathrm{s})$ & $10.24^{* *}$ & +57 \\
$"$ & $\mathrm{Mn}(\mathrm{b})$ & $10.13^{* *}$ & -38 \\
& $\mathrm{~K} / \mathrm{N}$ & $5.532^{*}$ & +29 \\
Ynde & & & \\
$"$ & $\mathrm{Al}(\mathrm{b})$ & $11.621^{* *}$ & +400 \\
$"$ & $\mathrm{Ca}(\mathrm{b})$ & $8.273^{*}$ & +35 \\
$"$ & $\mathrm{P}(\mathrm{e})$ & $5.901^{*}$ & +43 \\
& $\mathrm{~S}(\mathrm{~b})$ & $11.289^{*}$ & +14 \\
Maglehem & $\mathrm{Ca}(\mathrm{e})$ & $9.357^{*}$ & -18 \\
$"$ & $\mathrm{Fe}(\mathrm{b})$ & $5.163^{*}$ & -83 \\
$"$ & $\mathrm{~K}(\mathrm{~s})$ & $17.492^{* *}$ & -8 \\
$"$ & $\mathrm{Mg}(\mathrm{e})$ & $6.453^{*}$ & -35 \\
$"$ & $\mathrm{Mn}(\mathrm{e})$ & $7.868^{*}$ & -51 \\
$"$ & $\mathrm{P}(\mathrm{b})$ & $5.292^{*}$ & -3 \\
\hline
\end{tabular}

\section{DISCUSSION}

The nutrient levels in the bark of control trees did not differ much at the different sites, despite differing soil conditions and exposure to deposition. There might be a large variation in the concentration of elements between trees of one species, but the concentrations are within the 
Table V. Mean value and standard deviation for the index of injury, a measure of frost sensitivity in beech bark, on the five sites in August $\left(I_{t} \times A\right)$ and November $\left(I_{t} \times N\right)(n=56)$.

\begin{tabular}{lcc}
\hline & mean & SD \\
\hline$I_{\mathrm{t}} 10 \mathrm{~A}$ & 61.0 & 16 \\
$I_{\mathrm{t}} 20 \mathrm{~A}$ & 69.5 & 18 \\
$I_{\mathrm{t}} 10 \mathrm{~N}$ & 6.7 & 10 \\
$I_{\mathrm{t}} 20 \mathrm{~N}$ & 19.0 & 11 \\
\hline
\end{tabular}

ranges that are typical for each tree species [15]. The nutrient concentrations in xylem sap varies from season to season. It is lowest during the summer when the nutrient reserves are used and increases in late autumn when the leaves are shed [14]. Thus, the concentration of nutrients were analysed in August when it was expected that deficiency or excess of any element would be most pronounced. $\mathrm{N}$ was the least variable element, and this has also been recorded for beech leaves [3]. The reason would be that availability of $\mathrm{N}$ regulates growth. Concentrations of macronutrients were less variable than concentrations of micronutrients, probably due to analysis sensitivity and because contamination makes a larger difference to nutrients in low concentrations. The concentrations of $\mathrm{Mn}$ and $\mathrm{Fe}$ in the trees were more influenced by a high water table than acid soil conditions. Anaerobic conditions can damage the roots and cause lesions and both at Svenstorp and Ynde, dead and badly damaged trees were observed on the wet spots. The Al concentration in bark can be expected to reflect the acidity of the soil, since Al is not taken up by the trees as a nutrient. Compared to the concentration of nutrients in leaves from beeches grown in southern Sweden [3] the concentration of $\mathrm{Ca}$ was three times higher in the bark tissue. The concentration of other elements were 2-3 times lower in bark tissue than in leaves. This reflects the supportive function of the bark tissue with thicker cell walls and much lower photosynthetic capacity than the leaves. The same pattern was found for white spruce
[29], and for several tree species in a montane rain forest in New Guinea [15].

Complex forming metals, such as $\mathrm{Cu}$ and $\mathrm{Mn}$, bind strongly to cellulose and hemicellulose and cell wall proteins contain S [19], thus those elements showed low solubility in propanol solution. The sum of mineral nutrients in propanol extract (e) and nitric acid digest (b) is fairly comparable to the concentrations in bark samples digested in nitric acid only (= unextracted). Only the concentrations of $\mathrm{Cu}$ and $\mathrm{Na}$ did not correlate between extracted and unextracted samples (Jönsson unpubl.). Na is, in any case, not considered an essential element for plants [19].

At Floen the lime treatment had positive effects on the bark chemistry, with decreased Mn concentration and elevated $\mathrm{Ca} / \mathrm{Al}$ ratio. Liming could decrease the uptake of $\mathrm{B}, \mathrm{K}$ and $\mathrm{P}$ in trees, especially at high doses $[2,17$, 18]. A lower concentration of B was found in the bark of trees treated with lime at Svenstorp, whereas the $\mathrm{K}$ and $\mathrm{P}$ concentrations were neither affected at Svenstorp nor at Floen. Liming reduces negative effects of soil acidification, but missing nutrients other than $\mathrm{Ca}$ and $\mathrm{Mg}$ must be supplied by other means, for instance by treatment with wood ash. In this study, however, the levels of bark nutrients were not significantly affected by ash treatment. The base saturation of the soil had increased in 1995 , mostly in the mor layer but also in the mineral horizon [13]. There is a time delay between soil treatment and tree response [14], so perhaps the nutrient status within the trees will be affected in the future.

During the N-fertilization in Maglehem strong acidification, leaching of $\mathrm{NO}_{3}^{-}$and cations together with mobilization of $\mathrm{Al}$ and $\mathrm{Mn}$ were recorded in the soil [5]. In the leaves of fertilized trees the concentrations of total $\mathrm{N}$ and amino acids were elevated, and the concentrations of $\mathrm{P}, \mathrm{Cu}$ and phenolic compounds were lowered [4]. Old bark lesions were visible on the fertilized trees, but not on the control trees. The bark nutrient composition did not differ significantly among the different treatments seven years after the $\mathrm{N}$-fertilization, but the trees with bark lesions had lower concentrations of mineral

Table VI. Models for index of injury, produced by stepwise multiple regression of nutrients in bark extract (e) and extracted bark tissue (b). The elements are ranked in importance according to the standard partial regression coefficient. Values from treated and control plots at Floen, Konga, Maglehem and Ynde, $c=$ constant $(n=48)$.

\begin{tabular}{|c|c|c|c|c|}
\hline Index & Included elements & $r^{2}$ & $d f$ & $F$ \\
\hline$I_{\mathrm{t}} 10 \mathrm{~A}$ & $c(\mathrm{~S}(\mathrm{~b}), \mathrm{Ca}(\mathrm{b}), \mathrm{P}(\mathrm{b}), \mathrm{Zn}(\mathrm{b}), \mathrm{Na}(\mathrm{e}), \mathrm{Cu}(\mathrm{e}))$ & 0.46 & 6 & $5.74 * * *$ \\
\hline$I_{1} 20 \mathrm{~A}$ & $c(\mathrm{~S}(\mathrm{e}), \mathrm{Fe}(\mathrm{b}), \mathrm{Cu}(\mathrm{b}), \mathrm{Ca}(\mathrm{b}), \mathrm{Mg}(\mathrm{e}), \mathrm{B}(\mathrm{b}), \mathrm{K}(\mathrm{b}), \mathrm{P}(\mathrm{e}))$ & 0.58 & 8 & $6.76^{* * *}$ \\
\hline$I_{\mathrm{t}} 10 \mathrm{~N}$ & $c(\mathrm{Ca}(\mathrm{b}), \mathrm{S}(\mathrm{b}), \mathrm{Mg}(\mathrm{b}), \mathrm{Mg}(\mathrm{e}), \mathrm{Mn}(\mathrm{e}), \mathrm{Al}(\mathrm{b}), \mathrm{K}(\mathrm{b}), \mathrm{Cu}(\mathrm{e}), \mathrm{Fe}(\mathrm{b}))$ & 0.58 & 9 & $5.76^{* * *}$ \\
\hline$I_{\mathrm{t}} 20 \mathrm{~N}$ & $c(\mathrm{Ca}(\mathrm{b}), \mathrm{S}(\mathrm{b}), \mathrm{Fe}(\mathrm{e}), \mathrm{Mn}(\mathrm{b}), \mathrm{Fe}(\mathrm{b}), \mathrm{P}(\mathrm{b}), \mathrm{Na}(\mathrm{e}), \mathrm{Cu}(\mathrm{e}))$ & 0.41 & 8 & $3.42 * *$ \\
\hline
\end{tabular}


nutrients. The phloem tissue formed during the treatment was affected by the lowered soil concentrations of nutrients, and the trees most affected developed bark lesions. Since no new bark lesions were observed, this suggests that the negative effects of excessive $\mathrm{N}$ can be reversed if the load is removed. However, this, together with the lower $\mathrm{K}$ concentration and $\mathrm{K} / \mathrm{N}$ ratio in the bark of $\mathrm{N}$ fertilized trees at Konga, indicated that nutrient depletion has long-lasting impacts on the forest ecosystem. Conifers growing at $\mathrm{N}$-saturated sites showed signs of improved nutrient balance after 3-4 years with the concentration of $\mathrm{N}$ in the throughfall water reduced to a preindustrial level $[6,7]$. Calcium phosphate and aluminium phosphate were probably formed in the soil as a response to the addition of $\mathrm{P}$, and these low soluble complexes reduced the uptake of $\mathrm{Ca}$ and $\mathrm{Al}$ in the trees. This has been recorded for $\mathrm{Al}$ in beech seedlings [18].

Differences between undamaged trees and trees with lesions partly supported the second hypothesis. Higher concentrations of $\mathrm{N}$ and $\mathrm{Al}$ were found in trees with lesions, but lower concentration of base cations were only found at Maglehem. At Ynde the bark lesions were associated with a high Al concentration. At Maglehem the effects of the $\mathrm{N}$ fertilization were apparent. Also at Svenstorp, Floen and Konga bark lesions were associated with elevated $\mathrm{N}$ concentration (figure 2). The difference between trees with bark lesion and trees with undamaged stems was statistically significant only when all sites were analysed together, since the variation in concentration of $\mathrm{N}$ was low among the trees. A tree with lesions will allocate resources to the bark in order to repair the damage [20]. High concentration of $\mathrm{Ca}, \mathrm{K}, \mathrm{Mg}$ and $\mathrm{P}$ can reduce $\mathrm{Al}$ toxicity [1], and the elevated concentrations of these elements in trees with bark lesions indicated repairing processes. Approximately $98 \%$ of the $\mathrm{Ca}$ content is located in the cell walls, as indicated by extraction with propanol solution. Ca stabilises the cell walls [19], and high levels of Ca may therefore reduce the severity of the necrosis as observed by Perrin and Garbaye (1984).

Frost sensitivity was correlated to the nutrient concentrations. The nutrient concentrations have impact on the concentrations of carbohydrates, amino acids and fatty acid composition of membranes as well as the onset of hardening, all important for frost resistance [12]. Low levels of $\mathrm{Ca}$ in combination with high levels of $\mathrm{S}$ could be expected to occur on acid soils exposed to high deposition of $\mathrm{N}$ and S. I $20 \mathrm{~A}$ was the most severe treatment with low temperature and unhardened bark, and it is worth noting that the concentration of $\mathrm{Ca}$ (b) was not as important as in the multiple regressions of the other indices. The concentration of $\mathrm{N}$ was not incorporated in the multiple regressions, since the variation among the trees was low. Although the extractable concentrations of $\mathrm{K}, \mathrm{Mg}, \mathrm{S}$ and $\mathrm{Al}$ were strongly correlated to the conductivities of autoclaved samples, they were not important in the correlation to the indices of injury. To be able to fully understand the importance of nutrient balance for frost sensitivity controlled greenhouse experiments should be carried out.

\subsection{Conclusions}

Trees with bark lesions had higher concentrations of $\mathrm{N}$ and $\mathrm{Al}$, as well as elements connected to repairing processes. Locally, a high water table had a strong influence on the concentrations of $\mathrm{Mn}$ and Fe in bark. Liming reduced negative effects of soil acidification in the bark chemistry. Negative influence from $\mathrm{N}$ fertilization could be traced in the concentration of nutrients in the bark, but the absence of new lesions indicated that the vigour of the trees has increased during the seven years since last $\mathrm{N}$ fertilization. Differences in frost sensitivity between trees in southern Sweden can be attributed to differences in nutrient concentrations.

Other studies on the same sites have considered the influence of soil treatment and soil parameters on frost sensitivity (Jönsson, in press).

Acknowledgements: I am grateful to Professor Bengt Nihlgård for support during the study. I thank Irene Persson, Siv Billberg and Maj-Lis Gernersson, who performed the chemical analysis, and Abigail Sykes, who revised the language. This study was financially supported by the Swedish MISTRA foundation.

\section{REFERENCES}

[1] Andersson M., Toxicity and tolerance of aluminium in vascular plants, Water Air Soil Pollut. 39 (1988) 439-462.

[2] Aronsson A., Indikationer på stress vid obalans i trädens växtnäringsinnehåll, K. Skogs- o. Lantbr.akad. tidskr. Suppl. 17 (1985) 40-51 (in Swedish).

[3] Balsberg Påhlsson A.-M., Mineral nutrients, carbohydrates and phenolic compounds in leaves of beech (Fagus sylvatica L.) in southern Sweden as related to environmental factors, Tree Physiol. 5 (1989) 485-495.

[4] Balsberg Påhlsson A.-M., Influence of nitrogen fertilization on minerals, carbohydrates, amino acids and phenolic compounds in beech (Fagus sylvatica L.) leaves, Tree Physiol. 10 (1992) 93-100.

[5] Bergkvist B., Folkesson L., Soil acidification and element fluxes of a Fagus sylvatica forest as influenced by simulated nitrogen deposition, Water Air Soil Pollut. 65 (1992) 111133. 
[6] Boxman A., Van der Ven P., Roelofs J., Ecosystem recovery after a decrease in nitrogen input to a Scots pine stand at Ysselsteyn, the Netherlands, For. Ecol. Manag. 101 (1998) 155-163.

[7] Bredemeier M., Blanck K., Dohrenbusch A., Lamersdorf N., Meyer A.C., Murach D., Parth A., Xu Y.-J., The Solling roof project - site characteristics, experiments and results, For. Ecol. Manag. 101 (1998) 281-293.

[8] Burke M.K., Raynal D.J., Mitchell M.J., Soil nitrogen availability influences seasonal carbon allocation patterns in sugar maple (Acer saccharum), Can. J. For. Res. 22 (1992) 447-456.

[9] Evers F.H., Hüttl R.F., A new fertilization strategy in declining forests, Water Air Soil Pollut. 54 (1990/91) 495-508.

[10] Falkengren-Grerup U., Eriksson H., Changes in soil, vegetation and forest yield between 1947 and 1988 in beech and oak sites of southern Sweden, For. Ecol. Manag. 38 (1990) 37-53.

[11] Falkengren-Grerup U., Tyler G., Changes of cation pools of the topsoil in south Swedish beech forests between 1979 and 1989, Scand. J. For. Res. 6 (1991) 145-152.

[12] Fitter A.H., Hay R.K.M., Environmental physiology of plants, 2 ed. Academic press, London, ISBN 0-12-257764-7, 1993.

[13] Fransman B., Bramryd T., Barkaska som vitaliseringsmedel i samband med bokföryngring. Ynde-projektet, Ekol. inst. University of Lund. (In Swedish) 1996.

[14] Glavac V., Koenies H., Ebben U., Seasonal variations in mineral concentrations in the trunk xylem sap of beech (Fagus sylvatica L.) in a 42-year-old beech forest stand, New Phytol. 116 (1990) 47-54.

[15] Grubb P.J., Edwards P.J., Studies of mineral cycling in a montane rain forest in New Guinea, J. Ecol. 70 (1982) 623648.

[16] Hartmann G., Blank R., Etiology of oak decline in northern Germany. History, symptoms, biotic and climatic predisposition, pathology, in: Luisi N., Lerario P. and Vannini A (Eds.), Recent advances in studies on oak decline, Tipolitografia radio, Putignano Baic, ISBN 88-86337-00-0, 1993.

[17] Liljelund L.-E., Nihlgård B., in: Andersson F. and Persson T. (Eds.) Liming as a measure to improve soil and tree condition in areas affected by air pollution, Swedish Environmental Protection Agency report 3518, 1988.

[18] Ljungström M. and Nihlgård B., Effects of lime and phosphate additions on nutrient status and growth of beech (Fagus sylvatica L.) seedlings, For. Ecol. Manag. 74 (1995) 133-148.

[19] Marschner H., Mineral nutrition of higher plants, Academic press, Belfast, ISBN 0-12-473540-1, 1986.
[20] McLaughlin S.B., Shriner D.S., Allocation of resources to defence and repair, in: Horsfall J.G. and Cowling E.B. (Eds.), Plant disease, Vol. V. Academic Press, New York, ISBN 0-12-356405-0, 1980.

[21] Nihlgård B., Forest decline and environmental stress, in: Brune D., Chapman D.V., Gwynne M.D. and Pacyna J.M. (Eds.), The global environment; science, technology and management, Scandinavia Science Publ., Oslo, ISBN 3-527-28771x. 1997.

[22] Perrin R., Garbaye J., Influence de la nutrition de hêtre (Fagus sylvatica L.) sur la sensibilité au chancre provoqué par Nectria ditissima Tul., Ann. Sci. For. 41 (1984) 449-460 (in French).

[23] Scheffer, Schachtschabel P., Lehrbuch der Bodenkunde. 12ed., Ferdinand Enke Verlag, Stuttgart, ISBN 3 43284772 6, 1989.

[24] Skeffington R.A., Wilson E.J., Excess nitrogen deposition: Issues for consideration, Environ. Pollut. 54 (1988) 159184.

[25] Sokal R.R., Rohlf F.J., Biometry. 3ed., Freeman and Company, New York, ISBN 0-7167-2411-1, 1995.

[26] Sverdrup H., Warfvinge P., Critical loads of acidity for Swedish forest ecosystems, Ecol. Bull. 44 (1995) 75-89.

[27] Thomas F.M., Büttner G., Excess nitrogen, drought, and winter frost as possible predisposing factors of oak decline in northern Germany, in: Luisi N., Lerario P. and Vannini A. (Eds.), Recent advances in studies on oak decline, Tipolitografia radio, Putignano Baic, ISBN 88-86337-00-0, 1993.

[28] Thomas F.M., Blank R., The effect of excess nitrogen and of insect defoliation on the frost hardiness of bark tissue of adult oaks, Ann. Sci. For. 53 (1996) 395-406.

[29] Timmer V.R., Effect of fertilization on nutrient concentrations of white spruce foliage and bark, For. Sci. 25 (1979) 115-119.

[30] Tyler G., Acidification and Chemical Properties of Fagus sylvatica L. Forest Soils, Scand. J. For. Res. 2 (1987) 263-271.

[31] Ulrich B., Soil acidity and its relations to acid deposition, in: Ulrich B. and Pankrath J.D. (Eds.), Effects of accumulation of air pollution in forest ecosystems, Reidel Publ. Co., Dortrecht, 1983.

[32] Wargo P.M., Amino nitrogen and phenolic constituents of bark of American beech (Fagus grandifolia) and infestation by beech scale (Cryptococcus fagisuga), Eur. J. For. Pathol. 18 (1988) 279-290.

[33] Wargo P.M., Consequences of environmental stress on oak: predisposition to pathogens, Ann. Sci. For. 53 (1996) 359368. 